\title{
Poradenstvo v podpore profesijného rozvoja pedagogických zborov škôl ${ }^{1}$
}

\author{
Ivan Pavlov \\ Univerzita Mateja Bela, Pedagogická fakulta, katedra andragogiky
}

\begin{abstract}
Abstrakt: Systém a sústava podpory profesijného rozvoja učitel'stva prechádzala vo vývoji školstva mnohými zmenami. Nadobúdala rôzne ciele, obsahy, formy i metódy, ktoré sa stali predmetom pedeutologického výskumu a utvárania teórie učitel'skej profesie. Interdisciplinárny prístup pri skúmaní učitel'skej profesie sa v súčasnosti opiera aj o andragogiku (profesijnú), ktorá ponúka nové podnety najmä v otázkach profesijného učenia, vzdelávania i kariérového poradenstva zamestnaným dospelým. Príspevok popisuje východiská návrhu modelu andragogického kariérového poradenstva jednotlivcom a pedagogickým zborom škôl, ktorý reaguje na súčasnú absenciu komplexných programov podpory profesijného rozvoja učitel'stva na školách. Model andragogického poradenstva je ukotvený $v$ individualizovanej podpore, ale $v$ rámci pedagogického zboru, jeho potrieb a podmienok. Zásadný je obrat od externej, formálnej podpory nezohladňujúcej špecifické potreby pedagogických zborov $\mathrm{k}$ individualizovanému poradenstvu $\mathrm{v}$ kontexte života a práce pedagogického zboru školy.
\end{abstract}

Klúčové slová: učitel'stvo, profesijný rozvoj, profesijné učenie, andragogické poradenstvo

\section{Guidance in Support of Professional Development of Pedagogical Staff at Schools}

Abstract: Both the system and the framework of support of professional development of the teaching profession have faced many changes within the school system development. It included various aims, contents, forms and methods, which were subjected to the pedeutologic research and to the teaching profession creation. The interdisciplinary approach used in the teaching profession research is currently based also on andragogy (professional), which has been offering new inputs mainly in questions related to professional learning, education and career guidance provided to employed adults. Current article details principles of a proposed model of andragogic career guidance provided to individuals and pedagogical corps at schools, which reflects current absence of complex programmes supporting professional development of the teaching profession at schools. The model of andragogic guidance has been anchored in the individualised support, but framed within pedagogical corps at schools, their needs and conditions. Vital is an about-face from external, formal support not taking into account any specific needs of pedagogical corps towards individualised guidance in the context of life and work of pedagogical corps at a school.

Keywords: the teaching profession, professional support, professional learning, andragogic guidance

1 Štúdia vznikla aj vd'aka podpore projektu KEGA 003UMB-4/2016 Kariérny systém profesijného rozvoja učitelov a model podpory profesijného učenia na škole na katedre andragogiky Pedagogickej fakulty Univerzity Mateja Bela v Banskej Bystrici.

https://doi.org/10.14712/23363177.2019.6 www.orbisscholae.cz

(C) 2018 The Author. This is an open-access article distributed under the terms of the Creative Commons Attribution License (http://creativecommons.org/licenses/by/4.0), which permits unrestricted use, distribution, and reproduction in any medium, provided the original author and source are credited. 
32 Dynamika spoločenských zmien posledných desat'ročí sa zrkadlí v náročných požiadavkách na výkon učitel'skej profesie. Kvalifikačná príprava i ked' je pre profesiu rozhodujúca vyžaduje kontinuálne, celoživotne reagovat' na zmeny v školách. Znamená to byt' neustále pripravený aktualizovat', inovovat' a viest' k expertnosti svoju profesionalitu pri výkone pedagogickej činnosti. Trend predlžovania veku odchodu do dôchodku spôsobí, že učitel'ky a učitelia budú štyridsat' rokov počas profesijnej kariéry vystavení očakávaniam, s ktorými sa bude nevyhnutné vyrovnat'. Nepôjde len o podporu jednotlivcov, ale celých pedagogických zborov škôl, kde vnútorná diverzita ich členov (profesijná integrita, identita, kariérový rozvoj, potreby vzdelávania, výsledky pedagogickej činnosti a pod.) bude trvalou výzvou pre manažmenty škôl. Pre učitel'stvo nejde o novú situáciu, bola tu prítomná vždy a rovnako naliehavá (len z rôznych dôvodov), ale turbulencia súčasných zmien nemá obdobu.

\section{Teoretické základy a praktická podpora profesijného rozvoja učitel'stva}

Právom i povinnost'ou učitel'stva oddávna bola jeho aktívna účast' na profesijnom rozvoji (d’alšom vzdelávaní). Podpora učitel'stva v tomto úsilí má svoj teoretický základ vo vede označovanej ako pedeutológia. V Česku (Spilková \& Vašutová, 2008; Starý et al., 2012), v Pol'sku (Kwiatkovska, 2008) a na Slovensku (Kasáčová, 2004; Černotová, 2005) je pedeutológia vedou - teóriou učitel'skej profesie, s deklarovaným potenciálom analyzovat' všetky dimenzie, procesy a vzt’ahy súvisiace nielen s (pregraduálnou) prípravou na učitel'ské povolanie, ale aj s jeho samotným výkonom. Toto omnipotentné poňatie otvára diskusiu o jeho východiskách, opodstatnenosti a miere, $\checkmark$ akej podnecuje alebo bráni rozvoju systematického vedeckého štúdia učitel'skej profesie. Obsahová analýza pedeutologických prác posledných desat'ročí odhaluje niekolko diskrepancií súvisiacich s ponímaním predmetu, cielov a úloh pedeutológie. Zásadné je taxatívne ukotvenie pedeutológie $v$ pedagogike, ktoré je konfrontované so zretel'ným interdisciplinárnym charakterom jej predmetu skúmania (psychológia, sociológia, etika a iné), čo sa odráža aj v rôznych názoroch na hierarchické postavenie vedy (samostatná veda, vedná disciplína, subdisciplína apod.). Teória učitel'skej profesie nemá charakter samostatnej vedy, ale súboru teórií vznikajúcich ako produkcia špecifickej aplikácie prieniku rôznych vied a výkonu učitel'skej profesie (napr. sociológia učitel'skej profesie, psychológia učenia sa dospelých, učitel'stvo vo vzdelávacích politikách, história učitel'ského vzdelávania, manažment ludských zdrojov $v$ rezorte školstva, ekonomika školstva - sociálne a finančné zabezpečenie učitel'stva, učitel'ská etika a d'alšie). Klúčcvé je, že hoci je teória učitel'skej profesie kontextuálne orientovaná na pedagogickú sféru (výchova a vzdelávanie detí a mládeže), v metódach, formách a prostriedkoch podpory primárnej cielovej skupiny (učiteliek a učitelov) má najužší a legitímny vzt’ah k andragogike. Kosová (2007, s. 5) konštatuje, že „prienik andragogiky do pedeutológie by mohol v d'alšom vzdelávaní učitelov spôsobit' zásadné koncepčné zmeny“. 
Osobnost' dospelých a ich rozvoj, výchova a vzdelávanie a poradenstvo (vrátane profesijného) patrí na pôdu andragogiky (vedy o výchove, vzdelávaní a poradenstve dospelým). To vytvára potenciál andragogiky (zvlášt' profesijnej), napr. v oblasti podpory profesijného rozvoja, profesijného učenia sa učiteliek a učitelov ako jednotlivcov, ale aj učiacich sa tímov (učiacich sa škôl). Profesijná andragogika (v Českej republike personálna) je podla Průchu a Vetešku (2012, s. 208) aplikáciou andragogických teórií v prostredí pracovných organizácií. Špeciálne profesijné andragogiky skúmajú socioprofesijné skupiny zamestnancov pri výkone profesie (napr. zamestnanci verejnej a štátnej správy, obchodu a podnikania). Z tohto pohl'adu chápeme aj učitel'skú andragogiku ako špeciálnu profesijnú andragogiku - vedu o výchove, vzdelávaní a poradenstve socioprofesijnej skupiny - učitel'stva. Predmetom učitel'skej andragogiky je človek vo výkone učitel'skej profesie. Učitel'ka a učitel' sú učiaci sa dospelí l'udia (andragogický aspekt), ktorí sa ako zamestnanci v pracovnom prostredí d’alej vzdelávajú a rozvíjajú (aspekt profesijnej andragogiky). Konajú tak v súlade s potrebami svojho pracoviska (školy) a pedagogickej profesie, aby zlepšovali svoj celoživotný potenciál pre vyššiu kvalitu pedagogickej činnosti (aspekt učitel'skej andragogiky). Poňatie predmetu učitel'skej andragogiky chápeme (Pavlov \& Krystoň, 2017, s. 32) ako:

- Materiálny objekt - dospelý človek, spoločný predmet záujmu viacerých vedných odborov (napr. antropológia, psychológia, sociológia, etika a iné).

- Formálny objekt - hladisko, z ktorého veda svoj materiálny objekt skúma a ktoré určujú rozsah pôsobnosti (kde je andragogická veda nápomocná učitel'stvu):

- andragogická (profesijná) výchova a sebavýchova učitel'stva (napr. otázky profesijnej identity a integrity, etických princípov pri výkone profesie, etických kódexov a pod.);

- andragogické (profesijné) vzdelávanie a sebavzdelávanie učitel'stva (napr. podpora profesijného učenia sa a rozvoja profesijných kompetencií učitel'stva a pod.);

- andragogické (profesijné) poradenstvo učitel'stvu (napr. podpora individuálnych a tímových foriem profesijného učenia v podmienkach školskej organizácie, podpora kariérového rozvoja, jeho plánovanie, realizácia, hodnotenie a pod.).

Učitel'ská andragogika sa uplatňuje v troch dimenziách, ktoré vytvárajú nielen teoretický, ale aj praktický kontext pre napĺňanie jej účelu: personálna - ako štúdium predpokladov, činností a výsledkov výchovnej, vzdelávacej a poradenskej činnosti jednotlivcov $v$ učitel'skej pozícii a ich vzdelávatel'ov, t.j. lektorov, mentorov, tútorov, koučov, ale aj účastníkov (pracovných tímov); procesuálna - ako štúdium špecifických podmienok tvorby kurikula (ciele, obsahy, metódy, formy, prostriedky a pod.) vo výchove, vzdelávaní a poradenstve učitel'stvu; inštitucionálna - ako štúdium podmienok a prostredia poskytovatelov vzdelávacích a poradenských služieb učitel'stvu, ich manažovania a organizácie (verejný, súkromný i neziskový sektor).

Špecifický charakter učenia sa učitel'stva sa prejavuje v jeho konkrétnych vzdelávacích aktivitách. Podla Európskej komisie (2011, s. 35-41) na prelome osemdesiatych a devät'desiatych rokov minulého storočia bol profesijný rozvoj založený 
34 primárne na vzdelávaní sa $v$ odbore, ktoré formou školení malo viest' $\mathrm{k}$ pedagogickému majstrovstvu. Kritika neefektívnosti školení sa stala hnacou silou nového prekonceptovania profesijného rozvoja (a učenia sa) učitel'stva. Neskôr kognitívne teórie učenia inšpirovali vyučovacie metódy dospelých k záveru, že učenie sa učitel'stva má byt' chápané ako aktívny a konštruktívny proces, ktorý je problémovo orientovaný, zasadený do spoločenského prostredia a okolností a prebieha počas celého profesijného života. Následne bol definovaný pojem kontinuálneho a celoživotného vzdelávania učitel'stva v škole, ako prirodzená súčast' profesijných aktivít a podmienka dosiahnutia vyššej kvality školy.

Klúčová pre všetky dimenzie je otázka profesijného učenia. Ak chceme porozumiet' zvláštnostiam $v$ učení sa učitel'stva ako profesijnej skupiny, je potrebné poznat' psychologické základy učenia sa človeka v dospelosti a možnosti, ktoré pre učenie sa utvára špecifické pracovné - školské prostredie. Profesijné učenie predstavuje rôznorodé učebné aktivity orientované na osvojenie nových vedomostí, zručností, spôsobilostí zlepšujúcich kvalitu pedagogického procesu. Profesijný rozvoj v učitel'stve je procesom permanentného vyrovnávania sa so zmenami v profesii, ktorý zahŕňa všetky dimenzie rozvoja osobnosti učitel'ky a učitel'a a ich kompetencií. Súčasne vytvára osobnostné predpoklady a vnútornú motiváciu k spôsobilosti celoživotne využívat' príležitosti formálneho, neformálneho vzdelávania a informálneho učenia, na tvorivé zdokonalovanie kvality výkonu profesie - pedagogickej činnosti (Pavlov, 2017, s. 72). Rozlišujeme, či ide o učebné aktivity vyvolané, riadené vonkajšími podnetmi (školy, vzdelávacích inštitúcií a pod.) alebo ide o aktivity prameniace z vnútornej motivácie a profesijného presvedčenia - sebarozvoj učitel'a. Podla Lazarovej et al. (2012, s. 156) sú školy považované za špecifické organizácie alebo dokonca profesijné komunity, charakteristické nielen svojim poslaním, ale aj priestorovým usporiadaním, či štruktúrou pracovného času. Sú v nich teda aj špecifické podmienky pre rozvoj organizačného učenia. Výskumné štúdie sa pokúšajú objasnit’ vplyv kognície a motivácie na učenie sa alebo organizačné vzdelávanie $v$ profesijných učiacich sa spoločenstvách (spôsob, akým je škola organizovaná a vedená, je považovaný za hlavný nástroj zmeny a prepojenia profesijného rozvoja učitel'stva s rozvojom školy). Novotný, Pol a Hloušková (2011, s. 248-252) skúmali a porovnávali koncept organizačného učenia a koncept komunít profesijného učenia. Pre profesijný rozvoj učitel'stva je zásadné fungovanie školy podporujúcej spoluprácu medzi učitel'mi na úrovni individuálneho učenia, učenia malých tímov a učenia ako súčasti organizačnej práce školy. Kapacity, potenciál školy na podporu učenia na týchto úrovniach bývajú rôzne a ich komplexné pôsobenie napomáha efektivite profesijného učenia sa. Nejde len o demonštrovanie škôl ako profesionálnych vzdelávacích spoločenstiev, ale dôležité je skúmat' účinok na zmeny v stratégiách učitel'stva a učení sa žiakov. Orientácia na učenie (sa) žiaka a jeho potreby je hlavným prvkom úspešného profesijného učenia sa učitel'stva $v$ spoločenstvách. 


\section{Andragogické poradenstvo v profesijnom rozvoji a kariére učitel'stva}

Učitel'ská andragogika vytvára pre štúdium podpory profesijného rozvoja učitel'stva optimálny priestor tým, že je praktická, interdisciplinárna s orientáciou na otázky profesijného učenia, čím ponúka nový koncept, ktorý v najširšom význame spočíva $\checkmark$ podpore docility (vzdelatel'nosti) učiteliek a učitel'ov. ${ }^{2}$ Za najmenej rozvinutú a vedecky prepracovanú súčast' učitel'skej andragogiky považujeme - andragogické poradenstvo. Veteška (2016, s. 55) označuje andragogické poradenstvo ako samostatnú aplikovanú disciplínu o teórii, výskume a praxi poradenstva poskytovaného rôznym cielovým skupinám dospelých v rôznych životných etapách a s rôznym obsahovým zameraním. Ide teda o formu odbornej podpory rozvoja profesijných kompetencií cestou zefektívnenia profesijného učenia na úrovni jednotlivca (učitel'ky a učitel'a), učiacich sa tímov $v$ pedagogických zboroch a členov školského manažmentu, s predpokladaným dosahom na úroveň celej organizácie - školy. Andragogické profesijné poradenstvo disponuje diagnostickým, výskumným a intervenčným ( $v$ zmysle edukačné intervencie) potenciálom, ktorý odvodzujeme nielen z medzinárodných dokumentov (Rada EÚ, 2008), potrieb trhu práce a profesionalizácie učitel'stva, ale aj z logiky komponentov celoživotného poradenstva $v$ biodromálnom poňatí (školské pedagogické a psychologické poradenstvo, andragogické a geragogické poradenstvo). Tento koncept je rozvíjatel'ný na interdisciplinárnom prístupe skúmania pomoci a podpory dospelým v produktívnom veku pri výkone profesie (i po jej ukončení).

V odbornej literatúre sa stretávame s rôznymi poňatiami profesijnej kariéry. Prvé vychádza z gradačného (periodizovaného) prístupu, ktorý profesijnú dráhu v učitel'stve posudzuje napr. podla predpokladaného nárastu kvality profesijných výkonov, uvedomelých procesov utvárania schopnosti sebareflexie pedagogickej činnosti, schopnosti vyrovnat' sa so zvyšovaním psychickej zát'aže alebo postojov k pedagogickým zmenám (Maskit, 2011). Druhé poňatie je založené na individualizovanom prístupe, ktorý vychádza z myšlienky, že jedinečnost' učitel'skej osobnosti, neopakovatel'nost' pedagogických situácií, premenlivost' pracovného kontextu a špecifickost' podmienok na výkon profesie je nemožné vtesnat' do vopred stanovených štádií profesijnej kariéry. Obe poňatia sa zhodujú $v$ tom, že ide o celoživotný koncept sebarozvoja človeka ako zamestnanca počas celej jeho profesijnej dráhy, postupným získavaním pracovných skúseností, nových odborných kompetencií, zastávaní formálneho postavenia (pozície) v organizácii, ale aj tvorivé naplnenie vlastného potenciálu pre život a prácu. Pre učitel'skú profesiu (i kariéru) platí, že je stála a spravidla celoživotne viazaná na jednu organizáciu (výkon pedagogickej činnosti). Otázky kariéroveho poradenstva v učitel'stve dnes stoja na okraji záujmu vied, ktoré

2 Docilita (andragogický aspekt) má pôvod $v$ autoregulačných psychických procesoch osobnosti človeka, $v$ najširšom význame ako schopnost' regulovat' vlastné správanie a konanie. Každý má inú úroveň schopnosti autoregulácie sebaučenia danú neurologickými dispozíciami, podmienkami prostredia, školovaním, ale aj vhodnými edukačnými intervenciami. Docilita je diagnostikovatel'ný potenciál pre učenie, sebaučenie, ktorý je možné zlepšovat', rozvíjat', trénovat' a podporovat' aj andragogickou intervenciou. 
36 by mu mali venovat' pozornost'. Poradenstvom v pracovnej kariére (všeobecne) sa zaoberá kariérove poradenstvo (OECD, 2005; CEDEFOP, 2010; ELGPN, 2016), ale aj personalistika a manažment riadenia a rozvoja ludských zdrojov. CEDEFOP (2010, s. 28) konštatuje, že kariérové poradenstvo je spravidla vnímané ako nezávislé, primárne slúžiace jednotlivcovi, hoci sa uznáva, že istý prospech má z neho aj spoločnost' a zamestnávatel'ská organizácia. V našom poňatí (schéma 1) podpora profesijného rozvoja učitel'stva zahŕňa v najširšom význame vzdelávanie i poradenstvo. S ohl'adom na individuálnu profesijnú kariéru v podmienkach školy vyžaduje podporu pri formálnom (štruktúrovanom) kariérovom postupe, ale aj neformálnom kariérovom sebarozvoji (jednotlivcov i pedagogického zboru školy). V najhlbších štruktúrach procesov podpory rozvoja učitel'stva ide o individuálne (spoločné) profesijné učenie sa. Ide o rozvoj takých profesijných kompetencií, ktoré jednotlivcom a celým pedagogickým zborom umožnia efektívny kariérový postup a kariérový sebarozvoj za podpory vzdelávania a poradenstva.

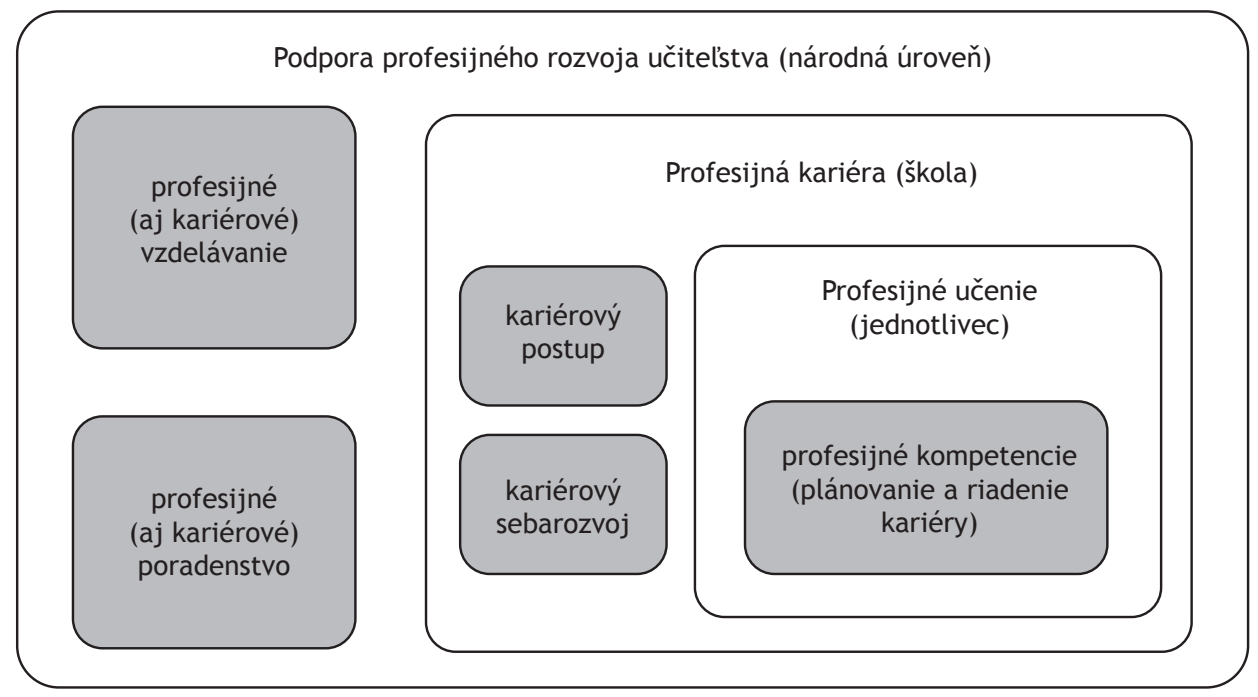

Obrázek 1 Viacúrovňový vzt’ah profesijného rozvoja a kariéry v učitel'stve. Vlastné spracovanie.

Úroveň teoretického skúmania (modelovania) kariéry učitel'stva je špecifickým prejavom podpory profesijného rozvoja a utvárania podmienok pre gradáciu profesijných kompetencií počas celej profesijnej dráhy (profesijný rozvoj nie je možné stotožnit' s profesijnou kariérou). Európska komisia (2018, s. 76-78) analyzovala existujúce kariérové systémy podpory učitel'stva, ktoré sú vel'mi rozmanité a spravidla predstavujú postup cez rôzne úrovne štruktúry kariéry $v$ zmysle získaných skúseností prostredníctvom nárastu zodpovednosti. V zlepšovaní profesijných kompetencií učitel'stva počas celej kariéry odporúča venovat' pozornost' profesijnému rozvoju, zmysluplným systémom hodnotenia a spätnej väzby, spolupráci medzi uči- 
tel'mi a kariérovej perspektíve. Vzdelávacie politiky na medzinárodnej i národných úrovniach hladajú efektívne nástroje podpory učitel'skej profesie. Zhodujú sa, že pre atraktívnost' učitel'ského povolania sú dôležité plat, zmluvné postavenie a jasné kariérne vyhliadky, obsahujúce stanovené úrovne kompetencií a štruktúru učitel'skej kariéry (EK 2017).

Systém podpory profesijného rozvoja učitel'stva na Slovensku dnes málo korešponduje s požiadavkami, ktoré formulovala Európska komisia (2012, s. 31-33). Od roku 2009 sa na Slovensku uplatňuje 3 kariérový model, ktorý má ambíciu komplexne poňat' profesijný rozvoj od pregraduálnej prípravy, adaptácie, stabilizácie, po expertnost' $v$ profesii. Zavedenie kariérového systému viedlo ku zvýšenému záujmu učitelov o ponuku formálnych aktivít kontinuálneho vzdelávania (motivovanú aj ziskom kreditov a financií) realizovanú zväčša externými poskytovatel'mi. Súčasný systém vykazuje negatívne znaky (MŠVVaŠ SR, 2017a; Pavlov, 2017; Santiago, 2016), ktoré v širšom kontexte kurikulárnych zmien po roku 2008 negatívne ovplyvnili odbornú pripravenost' učitel'stva ako hlavných aktérov školskej reformy (Kosová, 2017). V Českej republike viac ako dve desat'ročia prebieha odborná diskusia o zavedení kariérového systému pre učitel'stvo. V roku 2017 návrh nadobudol konkrétnu legislatívnu podobu zákona, ktorý nebol politicky priechodný a nerealizoval sa.

Podpora pri výkone učitel'skej profesie (verejný záujem), obsahuje dva principiálne prístupy: verejnú reguláciu formálneho vzdelávania (model kariéry v učitel'skej profesii) a verejnú podporu neformálneho vzdelávania a sebavzdelávania učitel'stva na školách. Oba prístupy komplexne vytvárajú podmienky pre podporu rozvoja profesijných kompetencií učitel'stva, ale stav na Slovensku je výrazne nevyvážený v neprospech podpory neformálneho vzdelávania a sebavzdelávania. Charakteristické je centralistické riadenie, uniformita foriem a metód vzdelávania potláčajúca tvorivý potenciál učiteliek a učitel'ov. Súčasný kariérový systém vytesnil podporu profesijného rozvoja (v širšom význame spontánne, dobrovol'né a neformálne aktivity) tým, že výrazne preferuje formálne vyjadrenie kvalít profesie na štyroch kariérových stupňoch. Kaščák a Pupala (2012, s. 147-156) poukazujú na neoliberálny vplyv založený na konštruktivistickej interpretácii formovania učitel'skej profesionality. Idea profesionalizácie učitel'stva legitimizovala štandardy profesie a vytvorila víziu pre individuálny kariérový rozvoj učitel'a. Ide o vonkajší, centralizovaný regulačný nástroj vzdelávania, ktorý sa uplatňuje permanentnou kontrolou profesijných výkonov cez výkonové indikátory, ktoré preberajú kontrolu nad sebarozvojom učitelov. Dôsledkom je potlačenie autonómie, sebavedomia učitel'ov ako kultúrne neistých a nerozhladených praktikov rezignujúcich na reprodukciu kultúrneho a historického vedomia (základov vzdelanosti), ale aj podriadenost' učitel'stva politickej moci a strata intelektuálnej významnosti, ktorá vytvárala sociálny vplyv na presadzovanie vlastných záujmov a pozitívnych sociálnych zmien. Na strane druhej stojí učitel' ako autonómny profesionál oddaný profesii, autoregulujúci a kriticky rozmýšlajúci nad svojou prácou, individuálne si určujúci ciele, metódy a formy svojho rozvoja v prostredí dôvery a podpory.

3 Zákon NR SR č. 317/2009 Z. z. 
Porozumenie tomu, ako sa z učitel'a stáva profesionál, sa odohráva na pozadí mnohých teoretických konceptov, vrátane konceptu profesijnej kariéry. Profesijnú kariéru $v$ učitel'stve chápeme ako subjektívny úspech učitelky a učitel'a pri výkone profesie alebo objektívny vzostup podla kariérového poriadku spojený s absolvovaním vzdelávacích aktivít, skúšok - atestov a následným finančným ohodnotením. Osobná kariéra je vnútorné uspokojenie s vykonávanou pracovnou (pedagogickou) činnost’ou v učitel'skej profesii. Osobný kariérový vývin predstavuje úspešnost' jednotlivých štádií profesijnej sebarealizácie na celoživotnej dráhe, ktorá nemusí byt' len vzostupná, úspešná a predvídatel'ná. Kariéra v učitel'stve sa v objektívnom význame môže vyjadrit' prostredníctvom nadobudnutých profesijných kompetencií diferencovaných podla špecifických kariérových ciest na kariérových stupňoch. Kariéra má význam pre všetkých aktérov, jednotlivcov (učitel'ky a učitelov), ale aj školy ako organizácie. Kariérový postup spravidla vedie $k$ vyššiemu finančnému oceneniu, profesijnému statusu, zastávaniu kariérových pozícií s vyššou zodpovednost'ou a prestiži v profesii. Kariérový rast je formálne upravený legislatívne ukotveným súborom pravidiel a požiadaviek - kariérový poriadok (určuje napr. kariérové cesty, podmienky dosiahnutia určitých stupňov v kariére - atestácie). Kariérové cesty (na Slovensku) predstavujú ponuku pre učitel'stvo na: udržiavanie profesijných kompetencií (kompenzačná funkcia), na dosiahnutie profesijných kompetencií vyššej kvality na kariérových stupňoch (expertná funkcia), na získanie špecifických profesijných kompetencií (špecializačná funkcia). Nastavenie funkčného kariérového systému vyžaduje neustávajúcu aktivitu odborníkov, trpezlivú diskusiu s praktikmi a skutočný záujem o prijatie rozhodnutí u politikov.

Profesijné poradenstvo nie je len funkciou vzdelávania, ale legitímny spôsob andragogického pôsobenia, ktoré sa dostáva do popredia pretože dopĺña vzdelávanie najmä tým, že viac zodpovedá individuálnym profesijným potrebám rozvoja učiteliek a učitel'ov. Kariérové poradenstvo je druhom andragogického poradenstva $v$ profesijnom učení a rozvoji. Andragogické kariérové poradenstvo $v$ učitel'stve, je novým edukologickým pojmom, ktorý zdôrazňuje legitimitu a význam andragogickej intervencie $v$ špecifických podmienkach výkonu učitel'skej profesie. Základnou úlohou andragogického kariérového poradenstva je podnecovanie procesov profesijného učenia a sebariadenia individuálnej kariéry učiteliek a učitel'ov. Ide o poradenstvo v problémoch, t’ažkostiach pri výkone učitel'skej profesie, ktoré sú riešitelné profesijným učením sa. Andragogickým kariérovym poradenstvom učitel'stvu rozumieme vedecky zdôvodnené, zámerné intervencie do sebariadenia kariéry jednotlivcov alebo pracovných tímov s cielom podporit' ich profesijný, kariérový rozvoj. Je to komplex poradenských služieb, ktoré sa orientujú na cielové skupiny:

- manažment škôl pri vytváraní podmienok a systémovú podporu a rozvoj individuálnej profesijnej kariéry zamestnancov i pedagogického zboru školy ako celku,

- učitel'ky a učitelov pri riadení vlastnej kariéry v profesii (ako jednotlivcov aj pracovné tímy). Ide o nastavenie subjektívne vnímaných vlastných schopností, profesijného sebapoňatia, sebaobrazu (presvedčenie, hodnoty, motívy a iné) sme- 
rujúceho k prekonávaniu prekážok, sebadôvere, stabilizácii a novým perspektívam sebarozvoja,

- poradcov profesijného rozvoja učiteliek, učitel'ov a manažmentu škôl na osvojenie a rozvoj kompetencií potrebných na poradenskú činnost'.

\section{Andragogické kariérové poradenstvo v praxi podpory profesijného rozvoja}

Profesijný rozvoj prebieha spontánne, ale aj ako súčast' vplyvu - podpory vonkajšieho prostredia. Podpora profesijného rozvoja je súbor podnetov, podmienok (inštitucionálne, legislatívne, materiálne, finančné, personálne a iné) pôsobiacich na skvalitňovanie práce učiteliek a učitel’ov zvonku školy alebo z jej vnútra. Môže mat' krátkodobý i dlhodobý charakter, líši sa poskytovatel'mi a zameraním, môže byt' súčast'ou povinnej ponuky (nové kurikulum, maturita, testy) alebo vyplývat' z vnútorných potrieb školy (ako dopyt po rozvoji). Môže byt' poskytovaná v úzkej súčinnosti so školou, ktorá je nielen objektom podpory, ale aj jej aktívnym subjektom (široké spektrum neformálnych aktivít, ktoré vznikajú na úrovni školy, z iniciatívy učitel'stva a je orientovaná na uspokojenie vzdelávacích potrieb a sebarozvoj v súlade s potrebami školy). Podpora profesijného rozvoja sa viac chápe ako efektívny prostriedok školsko-politických reforiem, než priama podpora efektívnych postupov profesijného učenia $v$ podmienkach školy. Na Slovensku dominuje paradigma založená na centralistickom riadení reformných zmien (Pavlov, 2017). Je potrebné posilnit' úlohu individuálneho sebarozvoja a intervencie ku spolupráci v jednotlivých školách, kde sú učitel'ky a učitelia priamo zapojení v procesoch svojho zlepšovania sa. Aktéri chápu účast' na budovaní vlastnej kariéry ako profesionálne právo i povinnost', učenie sa pri práci vnímajú ako zdroj podnetov rovnocenný iným aktivitám, pritom vyžadujú spätnú väzbu o účinnosti osvojených vedomostí a spôsobilostí v praxi. Chápu, že škola, kolegyne a kolegovia a spoločné učenie sa, je dôležitým zdrojom inšpirácií na realizáciu efektívnych stratégií učenia sa. Nielen zmena paradigmy podpory, ale aj absencia teoretických modelov, vrátane ich aplikačných interpretácií na podmienky škôl je prekážkou zmeny súčasného stavu. Manažmenty škôl nemajú k dispozícii nástroj (model), na základe ktorého by mohli efektívne a systematicky organizovat' a riadit' komplexný rozvoj profesijných kompetencií jednotlivcov a pedagogických zborov škôl v strednodobom i dlhodobom horizonte, tak aby boli principiálne prepojené s potrebami školy, na ktorej pôsobia. Absencia týchto modelov je zároveň prekážkou rozvoja potenciálu na využitie inovatívnych metód profesijného učenia sa na školách.

Model andragogického kariérového poradenstva je nástrojom organizačnej podpory profesijného rozvoja učitel'stva, cestou zefektívnenia profesijného učenia na úrovni jednotlivca (učitel'a a učitel'ských tímov a školského manažmentu), s predpokladaným dosahom na úroveň celej organizácie (Lazarová et al., 2016). Poradenstvo nie je výrazom deficitu, ale integrálnou súčast'ou celoživotného učenia (pomoc 
40 k svojpomoci), kde rozvoj kariéry nevychádza len z racionálneho, ekonomického základu, ale zohl'adňuje potreby človeka ako celku (Peavy, 2013). V uvedených konceptoch môže andragogické poradenstvo intervenovat' inovačnými stratégiami podpory profesijného učenia, individuálnym prístupom (kontraktom) bez striktnej štandardizácie priebehu (dížky a frekvencie poradenskej podpory atd'.), ktorá je predpokladom variantného (neterapeutického) využitia a individuálneho nastavenia (od jednorazových po dlhodobé kontrakty), smerujúceho k zvýšeniu individuálnej integrity, reflektívnosti a samostatnosti dospelých. Preventívny potenciál spočíva $\checkmark$ psychohygienickom efekte poradenstva, ktoré sa stáva priestorom pre rekonštrukciu a konceptualizáciu skúseností jednotlivca, uplatnenie holistického prístupu $\checkmark$ zmysle sprevádzania $v$ profesijnom rozvoji, so zohladnením referenčného rámca viazaného na biografiu, aktuálne (životné) situácie a profesijné potreby. Andragogické poradenstvo vyžaduje ujasnenie teoretických (interdisciplinárnych) východísk kariérového poradenstva a zakomponovanie prvkov efektívnych prístupov moderných poradenských systémov (naratívne, socio-dynamické, systemické, konštruktivistické a kompetenčné), čo umožní riešit’ problémy na úrovni jednotlivca aj na úrovni organizácie (Pattonová \& McMahonová, 2015).

Návrh modelu andragogického poradenstva $v$ podpore profesijného rozvoja sme orientovali na spoluprácu v učení - kompetenciu, ktorá je z pohl'adu našich empirických skúseností i výsledkov medzinárodných výskumov OECD (Kašparová, Potužníková, \& Janík 2015; Guerriero, et al., 2017; Tomengová et al., 2017) deficitná, avšak pre kariérový rozvoj zásadná. Učitel'ská kariéra v sebe zahŕňa aj rozvinutú spôsobilost' na spoluprácu, kolaboráciu medzi jednotlivcami a učiacimi sa tímami na škole. Podpora efektívnych modelov a stratégií profesijného učenia sa, ktoré vedú $\mathrm{k}$ lepším učebným výsledkom žiakov je dnes nevyhnutná. Aplikáciou inovačných stratégií v profesijnom učení môžeme očakávat' v krátkodobom horizonte zvýšenie záujmu o profesijný rozvoj a sebavzdelávanie, $v$ strednodobom horizonte zlepšenie výkonu pedagogickej činnosti, ktorá sa v perspektíve premietne do lepších učebných výsledkov žiakov. Model podpory profesijného rozvoja učitel'ov na škole (tabul'ka 1) pozostáva z niekol'kých vnútorne prepojených komponentov. Najprv ide o vertikálnu úroveň, v ktorej sa môžu procesy profesijného učenia realizovat' na úrovni celej školy ako organizácie, na úrovni učitel'ských tímov (napr. metodické združenia, predmetové komisie a iné neformálne učiace sa skupiny) alebo jednotlivcov (učitel'ky a učitelia). Pre každú z úrovní sme zvolili kritéria, ktoré reprezentujú klúčové znaky príznačné pre učenie podporujúce prostredie. Tieto kritériá sú pozorovatel'né (hodnotitel'né) cez súbor indikátorov a podliehajú $v$ rámci autoevalvácie školy spätnej väzbe a sebareflexii všetkých zúčastnených subjektov. Horizontálne tabul'ka umožňuje sledovat' každý komponent zvlášt', ale vo vzájomnej podmienenosti a prepojení s ostatnými. Návrh modelu je inštruktážny a orientuje každého $z$ aktérov na faktory, ktoré preukázatel'ne $\checkmark$ jeho pôsobnosti súvisia s podporou procesov profesijného učenia sa. 
Tabul'ka 1 Model podpory profesijného rozvoja učitel'ov na škole

\begin{tabular}{|c|c|c|c|c|}
\hline & Úroveň & Kritériá & Indikátory & Kritériá \\
\hline \multirow{6}{*}{ 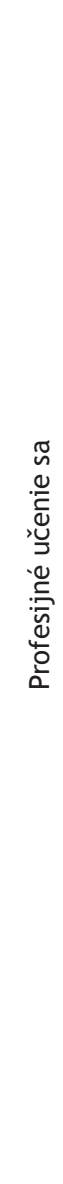 } & \multirow[b]{2}{*}{$\frac{\pi}{\frac{\pi}{i n}}$} & $\begin{array}{l}\text { Vzdelávací } \\
\text { program }\end{array}$ & $\begin{array}{l}\text { Súčast’ou je vízia profesijného rozvoja a kariéry } \\
\text { a podpora spoločného učenia. }\end{array}$ & \multirow{6}{*}{ 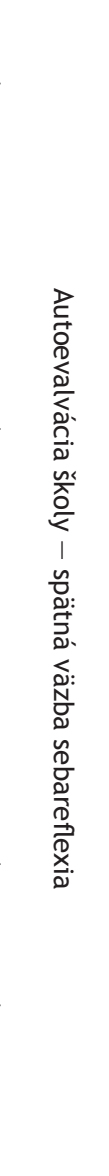 } \\
\hline & & $\begin{array}{l}\text { Plán podpory } \\
\text { profesijného } \\
\text { rozvoja }\end{array}$ & $\begin{array}{l}\text { Okrem zákonom stanovených druhov vzdelávania } \\
\text { obsahuje aj d’alšie spôsoby podpory profesijného } \\
\text { rozvoja (vrátane poradenstva) . } \\
\text { Podporuje transfer poznatkov a skúseností } \\
\text { z individuálneho vzdelávania do spoločného učenia sa } \\
\text { tímov. } \\
\text { Obsahuje nástroje na vyhodnotenie aplikácie modelu } \\
\text { podpory profesijného učenia a kariéry. }\end{array}$ & \\
\hline & 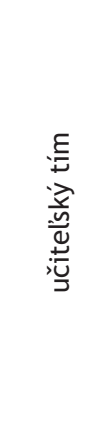 & $\begin{array}{l}\text { Spoločné/ } \\
\text { tímové } \\
\text { učenie sa } \\
\text { v škole } \\
\text { (vrátane } \\
\text { profesijného } \\
\text { poradenstva) }\end{array}$ & $\begin{array}{l}\text { Realizuje sa tímové medzipredmetové, predmetové } \\
\text { učenie, vzájomné hospitácie, tímové vyučovanie } \\
\text { a výmena didaktických materiálov pre výučbu. } \\
\text { Funguje komunikácia na riešenie pedagogických } \\
\text { problémov a vízií na škole. } \\
\text { Funguje transfer poznatkov a skúseností } \\
\text { z individuálneho vzdelávania do spoločného učenia sa } \\
\text { tímov na škole. } \\
\text { Tímy získavajú spätnú väzbu o dopadoch spoločného } \\
\text { učenia sa na výchovu a vzdelávanie žiakov. }\end{array}$ & \\
\hline & \multirow{3}{*}{ 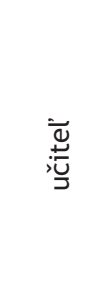 } & $\begin{array}{l}\text { Účast' na } \\
\text { vzdelávaní }\end{array}$ & $\begin{array}{l}\text { Učitelia sa vzdelávajú v súlade s víziou školy. } \\
\text { Učitelia sa vzdelávajú v súlade s vlastnými potrebami } \\
\text { a kariérovým plánom. }\end{array}$ & \\
\hline & & & Učitelia realizujú akčný pedagogický výskum. & \\
\hline & & $\begin{array}{l}\text { Seba } \\
\text {-vzdelávanie }\end{array}$ & $\begin{array}{l}\text { Učitelia zdiel'ajú reflektované poznatky a skúseností } \\
\text { z procesu výchovy a vzdelávania žiakov, ale aj } \\
\text { sebarozvoja v tímovom učení sa. }\end{array}$ & \\
\hline
\end{tabular}

Prevzaté a upravené z Pavlov a Krystoň (2017, s. 40).

V načrtnutom modeli andragogického kariérového poradenstva učitel'stvu sa perspektívne vytvárajú tieto obsahové okruhy (Pavlov, Bontová, \& Schubert 2017, s. 171-172, doplnené):

- podpora v rozvoji profesijných kompetencií, vrátane identifikácie učebných a vzdelávacích potrieb jednotlivcov (potenciálu na učenie - docility) a učiacich sa tímov, ale aj pri odhal'ovaní príčin profesijne nekompetentného správania a konania;

- podpora spôsobilosti autoregulácie v učení sa, zahŕňajúca diagnostiku a odporúčania na efektívne stratégie učenia sa;

- podpora v spracúvaní profesijných skúseností, zdiel'aní informácií z rôznych zdrojov alebo eliminácia t’ažkostí s aplikáciou osvojeného do pracovnej (pedagogickej) praxe; 
- podpora v plánovaní, realizácii, didaktickej transformácii vzdelávacích obsahov (učitel'ka a učitel' $v$ role učiaceho sa, resp. vzdelávatel'a dospelých kolegov);

- podpora pri individuálnej a skupinovej evidencii a evalvácii kompetencií a bilancovaní výsledkov profesijného učenia a jeho dopadoch na procesy učenia sa žiakov a organizačného učenia sa na škole;

- podpora $v$ riešení špecifických učebných potrieb a profesijných otázok (vol'ba vhodných programov vzdelávania, poskytovatel'ov, efektívnych a inovatívnych metód učenia, ale aj komunikačných modelov vo vzt’ahu k dospelým kolegom, rodičom, a i.);

- podpora vo výskume sebaučenia i učenia iných (kolegov, žiakov) z hl'adiska prínosu pre potenciál jednotlivca, tímu, organizácie;

- podpora pre školský manažment $v$ plánovaní a realizácii komplexného rozvoja organizácie (školy) cestami kontinuálneho vzdelávania a profesijného učenia na úrovni jednotlivcov a pracovných skupín (učiacich sa tímov);

- podpora v diagnostike kariérovej situácie, individuálneho potenciálu, plánovaní profesijnej kariéry, jej sebariadení, napredovaní i odstraňovaní bariér (stres, vyhorenie, nevhodná organizácia práce, zlé medzil'udské pracovné vzt’ahy a pod.). Úloha poradcov v profesijnom rozvoji (kariére) učitel'stva je klúčová. Správa medzinárodnej asociácie Educational and Vocational Guidance 2013 (Koštálová, \& Cudlínová, 2015, s. 44) uvádza, že úlohou poradcov je predovšetkým: posilňovat' rovnost' príležitostí $v$ spoločnosti (schopnost' spolupráce $v$ rámci diverzifikovaných skupín, ujasnit' si hodnoty), pomôct' klientom zorientovat' sa v ponuke možností, vyhodnocovat' príležitosti (vrátane alternatívnych pre znevýhodnené ciel'ové skupiny), podporit' klientov $v$ rozvoji potenciálu, podporit' otvorené prostredie a väčšiu participáciu vo verejnom dialógu všetkých cielových skupín, podporovat' rozvoj kritického myslenia a aktívne občianstvo (bez ohl'adu na profesijné zameranie). Poradcovia majú rozumiet' špecifikám výkonu profesie, podstate profesijného učenia a podpore profesijného učenia sa a rozvoja, zvláštnostiam poradenského vzt'ahu medzi poradcom a klientom, kontextom výkonu profesie, možnostiam a perspektívam učitel'skej kariéry a jej usmerňovania. V Európe bol navrhnutý univerzálny model obsahujúci kompetenčné štandardy (Schiersmann, 2016), ktorý zahŕňa tri funkčne a hierarchicky rozlíšené povolania $v$ kariérovom poradenstve: kariérový konzultant, poradca a špecialista. Tieto sú vymedzené kompetenčnými štandardami v oblastiach kariérovej výchovy a vzdelávania, hodnotenia a informácií, kariérového poradenstva, riadenia kariérových služieb, intervencií do sociálnych systémov a generickými odbornými kompetenciami. V segmente poradenstva učitel'stvu predpokladáme, že poradcami profesijného rozvoja sa môžu stat' tí, ktorí dnes pôsobia ako lektori, mentori, či tútori v profesijnom rozvoji učitel'stva. Perspektívne je zapojenie členov manažmentu škôl (Kto by mal lepšie rozumiet' a poradit' rozvojovým potrebám učitel'ov a pedagogického zboru než jeho riaditel?). Naše poňatie sa opiera o systémový prístup, kde je pôsobenie poradcov sústredené na podporu tých profesijných kompetencií učitel'stva, ktoré sú už dnes obsiahnuté v príslušnom profesijnom štandarde (MŠVVaŠ SR, 2017b). Na Slovensku ide o okruh kompetencií 
označovaný ako „profesijný rozvoj“, ktorý zahŕňa okrem iných aj vedomosti a spôsobilosti kariérového rozvoja. Stojíme pred úlohou, ako vedecky vysvetlit', obhájit’ a odborne - metodicky vyzbrojit' budúcich andragogických poradcov pre školskú prax. Podnetný pre učitel'skú profesiu sa nám javí návrh kompetenčného rámca, ktorý spracovali Hašková a Vaculík (2017, s. 89-90). Vykonali analýzu viacerých rámcov kompetencií pre riadenie vlastnej profesijnej kariéry (career management skills) a dospeli ku kompetenciám: sebepoznanie a pozitívne sebepoňatie, pozitívna interakcia s ostatnými a networking, reakcia na zmeny a rast, zapojenie a pozitívny prístup k celoživotnému učeniu, efektívne spracovávanie kariérových informácií, kariérové rozhodovanie, riadenie vlastnej kariéry a porozumenie roli jednotlivca v spoločnosti.

S prihliadnutím na vyššie uvedené východiská sme spracovali návrh vzdelávacieho programu na prípravu špecialistov - poradcov profesijného rozvoja učitelov (160 hodín v kombinovanej forme). Ponúka uchádzačom z radov pedagógov: školských inšpektorov, metodikov, riaditel'ov a učitelov škôl po úspešnom ukončení (obhajobou záverečnej práce) získat' špecializáciu na túto odbornú činnost'. Vzdelávací program v našom poňatí integruje všetky tri úrovne (konzultant, poradca a špecialista) vytvorené v rámci multilaterálneho projektu Európskej únie (Schiersmann, 2016, s. 42). Adaptuje navrhnuté kompetencie poradcov na špecifiká výkonu učitel'skej profesie a podmienok škôl. Absolvent si osvojí profesijné kompetencie, ktoré mu umožnia identifikovat' vzdelávacie potreby a úroveň autoregulácie v učení sa, poradensky komunikovat' na úrovni jednotlivca, skupiny a školy, vykonávat' rolu poradcu profesijného rozvoja, ovládat' zásady a fázy poradenského procesu a klientovi (jednotlivcovi i škole) navrhnút' aktivity podporujúce efektívne stratégie učenia. Obsah vzdelávania je štruktúrovaný do štyroch blokov: diagnostika vzdelávacích potrieb (diagnostické nástroje a metodika analýzy), interpersonálne zručnosti (poradenská komunikácia a poradenský vzt'ah, podpora autoregulácie učenia sa a sebarozvoja), kooperácia a partnerstvo (partnerská spolupráca pri spoločnom riešení problémov a skupinové aktivity v profesijnom učení), profesijný kontext (trendy v učitel'skej profesii, škola podporujúca profesijný rozvoj a efektívne stratégie profesijného učenia sa a kariérového sebarozvoja učitel'ov). Súčast’ou realizácie vzdelávania bude konzultačné stredisko, prostredníctvom ktorého budú účastníci i absolventi programu ponúkat' svoje poradenské služby školám a učitel’om.

Koncept andragogického kariérového poradenstva učitel'stvu je príspevkom do diskusie o efektívnej podpore jeho profesijného rozvoja na školách. Reaguje na predstavy, že prijatím akýchkol'vek centralistických a regulatívnych noriem je možné zabezpečit' zlepšovanie práce učitel'stva a výsledkov práce škôl. Nevystupuje v opozícii ku kariérovým systémom podpory, ani formálnym (vzdelávacím) aktivitám rozvoja učitel'stva, ale komplementárne ich dopĺňa o komponent poradenstva. Profesijné kariérové poradenstvo môže stimulovat' potenciál učitel'stva $k$ inovatívnym procesom učenia (sebaučenia) a pri sebariadení profesijnej kariéry. Rovnako môže podniet' potenciál manažmentu škôl viest' pedagogické zbory ku spoločnému úsiliu o plánovanie, podporu učitel'skej kariéry v súlade s jej potrebami. 


\section{Literatúra}

Cedefop. (2010). Profesijný rozvoj v práci. Prehl'ad kariérového poradenstva pre pracujúcich. Dostupné z http://web.saaic.sk/ nrcg_new/kniznica/CEDEFOP_RozvojvPraci/PRVP_2010 _web.pdf

Černotová, M. (2005). Potrebujú učitelia pedeutológiu? In B. Kasáčová (Ed.), História, súčasnost' a perspektívy učitel'ského vzdelávania. Zborník príspevkov z medzinárodnej konferencie, 1 diel.(s. 201-205). Banská Bystrica: Univerzita Mateja Bela.

The European Lifelong Guidance Policy Network. (2016). Doporučení pro rozvoj politik a systémů celoživotního poradenství. Referenční rámec pro EU a komisi. Dostupné z http:// www.euroguidance.cz/publikace/elgpn-tools-6.pdf.pdf.

European Commision. (2012). Supporting the teaching professions for better learning outcomes. Accompanying the document communication from the Commission Rethinking Education: Investing in skills for better socio-economic outcomes. Dostupné z http://ec.europa .eu/education/news/ rethinking/sw374_en.pdf.

European Commission / EACEA / Eurydice. (2018). Teaching careers in Europe: Access, progression and support. Eurydice Report. Dostupné z https: / / eacea.ec.europa.eu/national-policies /eurydice/content/teaching-careers-europe-access-progression-and-support_en

Európska komisia. (2011). Zvyšovanie efektívnosti vzdelávania prostredníctvom profesijného rozvoja učitelov. Bratislava: Metodicko-pedagogické centrum.

Európska komisia. (2017). Rozvoj škôl a excelentná výučba: klúč pre výborný štart do života. Dostupné z https://eur-lex.europa.eu/legal-content/SK/TXT/PDF/?uri=CELEX : 52017DC0248\&from=SK

Európska únia, Rada EÚ. (2008). Lepšie začlenenie poradenstva do stratégií celoživotného vzdelávania. Dostupné z http://eur-lex.europa.eu/legal-content/SK/TXT/PDF/?uri = CELEX:42008X1213(02)\&from=SK

Guerriero, S., Ansari, D., Blömeke, S., Deligiannidi, K., König, J., Lauermann, F., ... Toledo-Figueroa, D. (2017). Pedagogical knowledge and the changing nature of the teaching profession. Dostupné z http://dx.doi.org/ 10.1787/9789264270695-en

Hašková, K. , \& Vaculík, M. (2016). Kariérní kompetence a možnosti jejich využití v kariérovém poradenství v České republice. Lifelong Learning - Celoživotní vzdělávání, 3(3), 81-101.

Kasáčová, B. (2004). Učitel'ská profesia v trendoch teórie a praxe. Prešov: Metodicko-pedagogické centrum.

Kaščák, O., \& Pupala, B. (2012). Škola zlatých golierov. Vzdelávanie v ére neoliberalizmu. Praha: Sociologické nakladatelství SLON.

Kašparová, V., Potužníková, E., Janík, T. (2015). Subjektivně vnímaná zdatnost učitelů v kontextu jejich profesního vzdělávaní: zjištení a výzvy z šetření TALIS 2013. Pedagogická orientace, 25(4), 528-556.

Kosová, B. (2007). Andragogický pohl'ad na vzdelávanie a učenie sa učitelov. Orbis scholae, 1(3), 5-12.

Kosová, B. (2017). Učitelia v reformách školy a kurikula. Edukácia. Vedecko-odborný časopis, 2(1), 126-138.

Koštálová, H., \& Cudlínová, M. (2015). Praktický průvodce kariérového poradce pre 21. století. Dostupné z http://www.ekscr.cz/sites/ default/files/obrazky/soubory/ publikace /stahnetesimetodiku_0.pdf

Kwiatkovska, H. (2008). Pedeutologia. Warszawa: Wydawnictwa Akademickie i Profesjonalne.

Lazarová, B., Pol, M., Hloušková, L., Novotný, P., \& Sedláček, M. (2012). Organizační učení v odborných diskurzech. Pedagogická orientace, 22(2), 145-161.

Lazarová, B., Sträng, D. R., Jensen, R., \& Sørmo, D. (2016). Podpora učení ve školách. Brno: Masarykova univerzita.

Maskit, D. (2011). Teachers' attitudes toward pedagogical changes during various stages of professional development. Teaching and Teacher Education, 27(5), 851-860.

MŠVVaŠ SR. (2017a). Analýza kariérového systému učitelov na Slovensku. Dostupné z http:// www.minedu.sk/diskusna-studia-analyza-karieroveho-systemu-ucitelov-na-slovensku/ 
MŠVVaŠ SR. (2017b). Pokyn ministra č. 39/2017, ktorým sa vydávajú profesijné štandardy pre jednotlivé kategórie a podkategórie pedagogických zamestnancov a odborných zamestnancov škôl a školských zariadení. Dostupné z https://www.minedu.sk/pokyn -ministra-c-392017-ktorym-sa-vydavaju-profesijne-standardy-pre jednotlive-kategorie -a-podkategorie-pedagogickych-zamestnancov-a-odbornych-zamestnancov-skol-a-skolskych -zariadeni

Novotný, P., Pol, M., \& Hloušková, L. (2011). Škola jako komunita profesního učení. In O. Kaščák \& B. Pupala (Eds.), Škola - statický element v sociálnej dynamike (s. 248-253). Bratislava: lura Edition.

OECD. (2005). Kariérové poradenstvo. Príručka pre tvorcov koncepcií. Dostupné z http: //web .saaic.sk/nrcg_new/kniznica\% 5COECD-KP_prirucka\%5CKarierove_poradenstvo-Koncepcna _prirucka.pdf

Pattonová, W., \& McMahonová, M. (2015). Kariérový rozvoj a systémová teorie. Propojení mezi teorií a praxí. Dostupné z http://www.dzs.cz/file/4963/EG_Karierovy \%20rozvoj\%20a\%20 systemova\%20teorie_2015.pdf

Pavlov, I. (2017). Učitel'ská andragogika. Prešov: Vydavatel'stvo Prešovskej univerzity.

Pavlov, I., Bontová, A., \& Schubert, M. (2017). Učitel'ská andragogika a model andragogického poradenstva. In J. Veteška (Ed.), Vzdělávaní dospělých 2016 - východiska a inspirace pro teorii a praxi (s. 165-175). Praha: Česká andragogická společnost.

Pavlov, I., \& Krystoň, M. (2017). Model podpory profesijného učenia a rozvoja učitel'stva. In I. Pavlov (Ed.), Kontexty podpory profesijného rozvoja učitel'stva (s. 9-48). Banská Bystrica: Belianum.

Peavy, V. R. (2013). Sociodynamické poradenství. Konstruktivistická perspektiva. Praha: Dům zahraniční spolupráce pro Centrum Euroguidance.

Průcha, J., \& Veteška, J. (2012). Andragogický slovník. Praha: Grada.

Santiago, P., Halász, G., Levačič, R., \& Shewbridge, C. (2016). OECD Review of schol resources: Slovak Republic. Dostupné z http://www.oecd-ilibrary.org/education/oecd-reviews -of-school-resources-slovak-republic-2015_9789264247567-en

Schiersmann, C., Einarsdóttir, S., Katsarov, J., Lerkkanen,J., Mulvey, R., Pouyaud, J., ... Weber, P. (2016). European competence standards for the academic training of career practitioners. Handbook Volume 2. Dostupné z http://www.nice-network.eu/cpr/ecs/

Spilková, V., \& Vašutová, J. (2008). Učitelská profese v měnících se požadavcích na vzdělávání: výzkumný záměr. Praha: Pedagogická fakulta Univerzity Karlovy.

Starý, K., Dvořák, D., Greger, D., \& Duschinská, K. (2012). Profesní rozvoj učitelů. Praha: Karolinum.

Tomengová, A., Kosová, B., Poliach, V., Pavlov, I., ŠukolovÁ, D., Fridrichová, P., ... Haviar, M. (2017). Pedagogické znalosti a profesionalita učitela. Banská Bystrica: Belianum.

Veteška, J. (2016). Přehled andragogiky. Praha: Portál.

Zákon NR SR č. 317/2009 Z. z. o pedagogických zamestnancoch a odborných zamestnancoch a o zmene a doplnení niektorých zákonov. Zbierka zákonov, 113, 2334-2361.

Doc. PaedDr. Ivan Pavlov, Ph.D. Pedagogická fakulta, Univerzita Mateja Bela Ružová 13, 97411 Banská Bystrica ivan.pavlov@umb.sk 